\title{
The tectonic framework of the Precambrian shield of Greenland. A review of new isotopic evidence
}

\author{
F. Kalsbeek
}

\begin{abstract}
There is now reliable isotopic evidence that most of the crystalline basement of Greenland consists of Archaean ( $>2500 \mathrm{Ma}$ ) rocks: only in the Ketilidian mobile belt of southernmost Greenland no Archaean rocks have yet been found. Proterozoic orogenic activity was widespread in the Nagssugtoqidian and Rinkian mobile belts of central and northern West Greenland, and peaked at c. $1850 \mathrm{Ma}$. There is some evidence that the Nagssugtoqidian mobile belt may define the boundary between two once separate Archaean continental plates and it is possible that comparable plate boundaries also exist elsewhere in Greenland.
\end{abstract}

\section{Introduction}

The Archaean craton of southern Greenland is bordered to the north and south by Proterozoic mobile belts (fig. 1). These main divisions within the Greenland shield were first established on the basis of field investigations: the Nagssugtoqidian mobile belt to the north was differentiated from the craton by Ramberg (1948), and the Ketilidian mobile belt south of the craton (Wegmann, 1938) was shown to be younger than the bordering Archaean rocks during field work in the early sixties (Bondesen, 1970). Later isotope evidence has confirmed this subdivision and not only provided information on the age of the various rocks but also on their mutual relations.

The Archaean age (i.e. $>2500 \mathrm{Ma} ; 1 \mathrm{Ma}=10^{6}$ years) of most of the rocks in the craton has been demonstrated in a large number of papers, reviewed, among others, by Bridgwater et al. (1976). On the basis of field work by McGregor (1973), Black et al. (1971) found that in the Godthåbsfjord area both early Archaean (3800-3600 Ma) and late Archaean (3000-2600 Ma) rocks could be distinguished. For the Ketilidian mobile belt to the south of the craton Proterozoic ages were first determined by van Breemen et al. (1974) and by Gulson \& Krogh (1975).

Field work had suggested that Archaean rocks continued into areas north of the Archaean craton, and the Nagssugtoqidian mobile belt was thought to consist mainly of Archaean rocks deformed and metamorphosed during the Nagssugtoqidian orogeny (Escher \& Watt, 1976; Escher et al., 1976). Farther north, preliminary isotope data suggested the presence of Archaean rocks far into the northern part of West Greenland (Kalsbeek, 1981). This region belongs to the Rinkian mobile belt which is differentiated from the Nagssugtoqidian mobile belt by its distinctive tectonic style (Escher \& Pulvertaft, 1976). Because of strong Proterozoic deformation and metamorphism of the rocks, the Archaean isotope relations are here often disturbed, and reliable age determinations by the Rb-Sr method can in general not be obtained. 


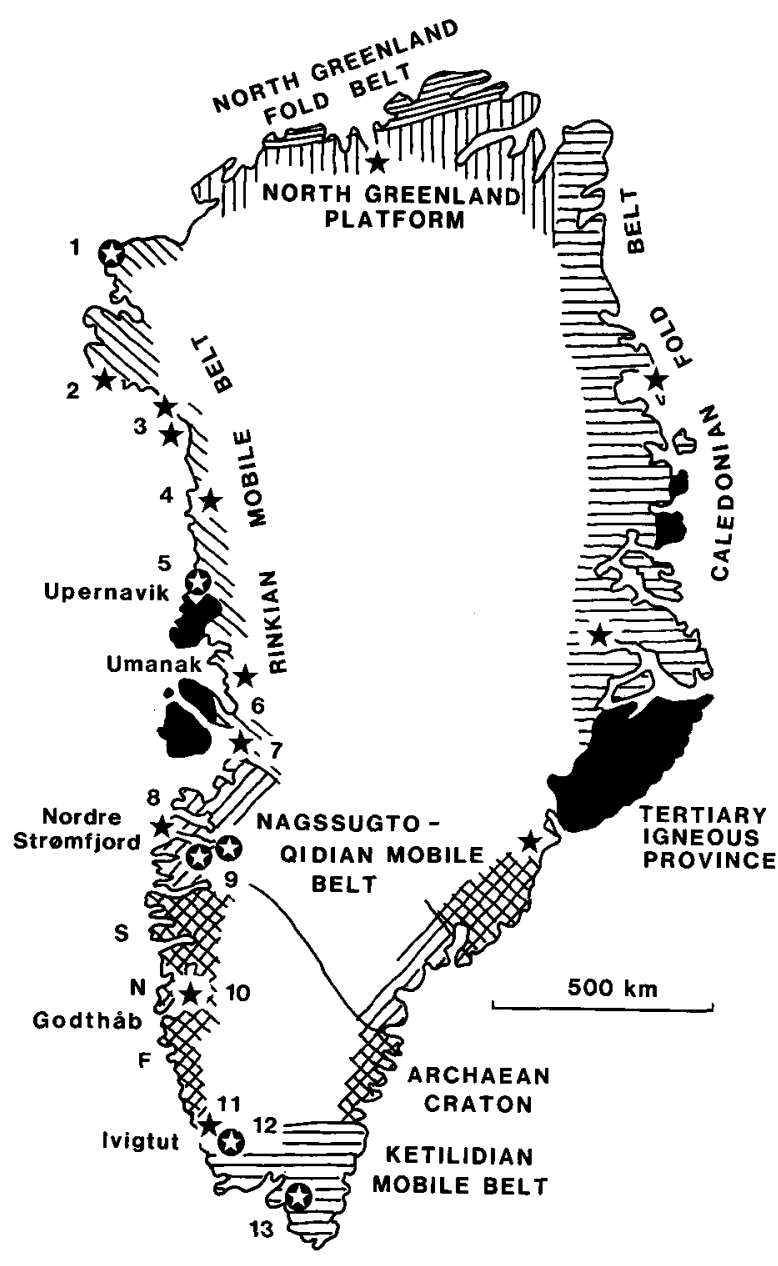

Fig. 1. Sketch of the main geological divisions in Greenland with localities mentioned in the text numbered. S: Sukkertoppen; N: Nordlandet; F: Fiskenæsset. Filled stars indicate the presence of proven Archaean rocks; open stars indicate Proterozoic rocks - see the text. For a discussion of the occurrence of Archaean rocks in East Greenland, see Kalsbeek (1981).

The regional geochronological investigation of Greenland has now been expanded to include isotope systems that are less readily upset by later metamorphism, and this paper summarises our present knowledge of the regional distribution of Archaean and Proterozoic rocks in the western half of Greenland. It is largely based on data from three sources: $\mathrm{Rb}-\mathrm{Sr}$ isotope data obtained at the isotope laboratory of the Institute of Petrology, University of Copenhagen, in cooperation with GGU geologists and O. Larsen (Copenhagen University); $\mathrm{Pb}-\mathrm{Pb}$ and $\mathrm{Rb}-\mathrm{Sr}$ isotope work carried out at the University of Oxford in cooperation with $\mathrm{S}$. Moorbath and P. N. Taylor; and zircon U-Pb age determinations carried out by R. T. Pidgeon (Western Australian Institute of Technology) for the Geological Survey of Greenland.

\section{The Rinkian mobile belt}

Fig. 1 and Table 1 give a synopsis of reliable evidence for the presence of Archaean and Proterozoic rocks north of the Archaean craton. In the Rinkian mobile belt a crystalline 
Table 1. Recent isotopic age determinations on gneisses and granitic rocks from West Greenland

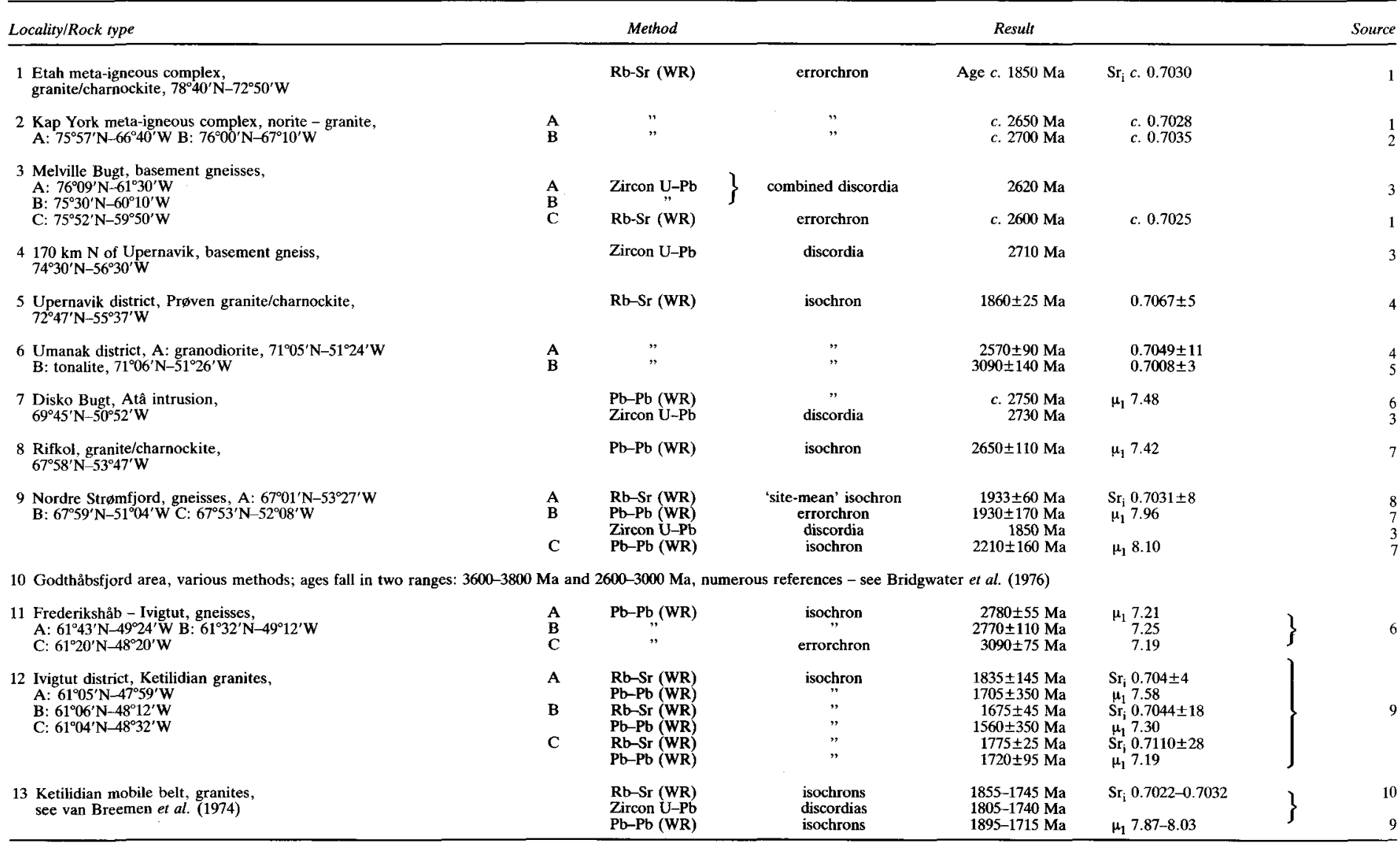

Locality: numbers as in fig. 1 . In most cases the samples come from a larger area and the geographical coordinates are therefore approximate. Method: WR $=$ whole-rock. Result: 'isochron' is used where the samples in the isochron diagram fit within analytical precision on a line; otherwise the term 'errorchron' is used. All precisions are given at the $95 \%$ level of confidence, and modern decay constants (Stieger \& Jager, 1977) were used throughout. $\mathrm{Sr}_{\mathrm{i}}$ is the initial ${ }^{87} \mathrm{Sr}{ }^{86} \mathrm{Sr}$ ratio; the uncertainties refer to the last digit(s) of the $\mathrm{Sr}_{\mathrm{i}}$ value shown. For an explanation of the model $\mu_{i}$ value see the text. Sources: 1 . P. R. Da-

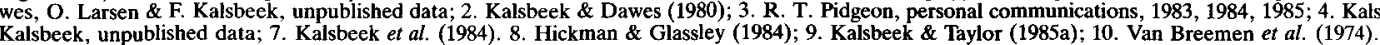


basement is overlain by a thick sequence of metamorphosed supracrustal rocks. For the basement rocks Archaean zircon U-Pb ages have been obtained from two localities in Melville Bugt and from the area north of Upernavik (localities 3 and 4, fig. 1; R. T. Pidgeon, personal communications, 1983 and 1984), and even in northernmost Greenland Archaean ages have recently been determined for granitic rocks in the basement underlying the North Greenland platform (B. T. Hansen, personal communication, 1985). New Rb-Sr isotope data for the intrusive rocks of the Kap York complex (2, fig. 1), obtained by O. Larsen in cooperation with P. R. Dawes (GGU) and the writer, have confirmed the Archaean age of this complex suggested by Kalsbeek \& Dawes (1980), and rocks from the Umanak district (6, fig. 1) have also given undoubted Archaean ages (Kalsbeek, 1981; Andersen, 1981). The Archaean age of the crystalline basement in the Rinkian mobile belt is thus now well established.

The Atâ intrusion in the northeastern part of Disko Bugt (loc. 7 in fig. 1) has also yielded an Archaean age (c. $2750 \mathrm{Ma}, \mathrm{Pb}-\mathrm{Pb}$ and $\mathrm{U}-\mathrm{Pb}$ zircon data; Taylor \& Kalsbeek, unpublished; R. T. Pidgeon, personal communication, 1985). Unlike most other Archaean rocks in the Rinkian mobile belt, the rocks of the Atâ intrusion are at many localities undisturbed by later deformation and metamorphism, and it appears therefore that Proterozoic orogenic activity was not significant here.

The age of the supracrustal rocks in the Rinkian mobile belt is not well known. They rest unconformably on late Archaean rocks in the Umanak district (Garde \& Pulvertaft, 1976) and are cut by c. $1850 \mathrm{Ma}$ intrusive rocks in the area around Upernavik (Kalsbeek, 1981). An early Proterozoic age of deposition seems therefore likely.

At several localities the Rinkian mobile belt contains Proterozoic intrusive rocks. The Prøven granite/charnockite near Upernavik (5, fig. 1) and rocks from the Etah meta-igneous complex in northernmost West Greenland (1, fig. 1) have given $\mathrm{Rb}-\mathrm{Sr}$ isochron ages of $c$. $1850 \mathrm{Ma}$ (Kalsbeek, 1981; O. Larsen, personal communication, 1984), and were apparently formed in connection with the metamorphic maximum at that time. Most of the Rinkian mobile belt has not yet been mapped in detail and the number of isotopic age determinations is so far very restricted. It is therefore uncertain how common Proterozoic intrusive rocks are and how they relate to the surrounding Archaean rocks.

Metamorphic ages of $c .1700$ to 1850 Ma have been obtained for the supracrustal rocks by the $\mathrm{Rb}-\mathrm{Sr}$ and $\mathrm{Pb}-\mathrm{Pb}$ isochron methods (Kalsbeek, 1981; Kalsbeek et al., 1984). The peak of metamorphism was probably at c. $1850 \mathrm{Ma}$ (Kalsbeek et al., 1984). K-Ar biotite ages in the Rinkian mobile belt are in the order of 1700-1750 Ma (Larsen \& Møller, 1968) and date the waning phases of metamorphism. An undeformed and very fresh basic dyke in the Rinkian mobile belt with well-preserved olivine has yielded a Rb-Sr isochron age of $1645 \pm 35 \mathrm{Ma}$ (Kalsbeek \& Taylor, unpublished). Apparently, by that time deformation and metamorphism had ceased completely.

\section{The Nagssugtoqidian mobile belt}

The Nagssugtoqidian mobile belt was differentiated from the Archaean craton on the basis of the 'Kangâmiut dykes', which form well preserved dolerite dykes in the craton, but become strongly attenuated and boudinaged amphibolite layers in the Nagssugtoqidian gneisses to the north (Ramberg, 1948; Escher et al., 1976). The Kangâmiut dykes have been dated at c. $1950 \mathrm{Ma}$ (Kalsbeek et al., 1978), and the main phase of Nagssugtoqidian metamorphism and deformation took place, as in the Rinkian mobile belt, at c. $1850 \mathrm{Ma}$. 
Since Ramberg's (1948) first description of the Nagssugtoqidian mobile belt it has been assumed that most of the area consists of deformed Archaean gneisses, and recent isotope studies have confirmed this (Hickman \& Glassley, 1984; Kalsbeek \& Taylor, unpublished data). A granite body on the island of Rifkol (8, fig. 1), for example, has given a $\mathrm{Pb}-\mathrm{Pb}$ isochron age of $c$. $2650 \mathrm{Ma}$ (Kalsbeek et al., 1984). However, it was also found that part of the gneisses that make up the mobile belt give Proterozoic ages (two localities in Nordre Strømfjord, 9 in fig. 1), and zircon U-Pb data obtained by R. T. Pidgeon (personal communication, 1983) confirm the Proterozoic age (c. $1850 \mathrm{Ma}$ ) of these rocks. Hickman \& Glasley (1984) obtained good $\mathrm{Rb}$-Sr isochrons on gneisses from Tiggait, slightly farther to the west in Nordre Strømfjord, which yielded Proterozoic ages ('site-mean' age $1933 \pm 60$ Ma, see Table 1). However, they interpreted this result as due to thorough resetting of the Sr-isotopic composition of original Archaean rocks.

In the Nagssugtoqidian mobile belt distinct 'linear belts' - in which there is a strong parallelism for all structural elements - alternate with areas of more open folding. It was thought that the latter were areas that had largely escaped the Nagssugtoqidian deformation, and that Archaean structures were here preserved (Escher et al., 1976). However, one of the gneiss localities that have given Proterozoic $\mathrm{Pb}-\mathrm{Pb}$ isochron and zircon $\mathrm{U}-\mathrm{Pb}$ ages lies within one of these areas and forms part of the 'pre-Nagssugtoqidian' structures. These structures cannot, therefore, be of Archaean age, but must have formed during the Proterozoic Nagssugtoqidian orogeny, before the formation of the neighbouring linear belts, which, as a consequence, must also be Proterozoic. Rb-Sr isotope evidence has shown, however, that some of the shear zones near the southern border of the Nagssugtoqidian mobile belt date back to the late Archaean (c. 2600 Ma; Kalsbeek \& Zeck, 1978, in press; Hickman, 1979; Kalsbeek, 1979). Apparently, the tectonic development of the Nagssugtoqidian mobile belt was complicated, and many details are as yet not well known.

Supracrustal rocks in the Nagssugtoqidian mobile belt have yielded Proterozoic $\mathrm{Pb}-\mathrm{Pb}$ whole-rock isochron ages of c. $1850 \mathrm{Ma}$ (Kalsbeek et al., 1984). These date the metamorphism of the rocks and the age of deposition is uncertain. Circumstantial lithological and field evidence, however, suggests that these supracrustal rocks correlate with those in the Rinkian mobile belt and, like those, were deposited during the early Proterozoic (Kalsbeek et al., 1984). Pb-isotope data obtained from marbles in the Rinkian and Nagssugtoqidian mobile belts support this view. The rocks yield ages of $c .1850 \mathrm{Ma}$, dating the time of metamorphism, but the data also strongly suggest that deposition of the sediments cannot have taken place more than at most a few hundred million years earlier than the metamorphism at $1850 \mathrm{Ma}$ (P. N. Taylor, personal communication, 1984).

\section{The Archaean craton and the Ketilidian mobile belt}

Whereas much isotopic information is available for the central part of the Archaean craton, very little has been published for the northern and southern parts of the craton. Likewise, isotopic data from the Ketilidian mobile belt are as yet limited. During the mapping in the fifties it was thought that the Ketilidian mobile belt contained an Archaean basement. For example, in the legend of the 1:100 000 map sheet $60 \mathrm{~V} .1$ Syd (Nanortalik), some gneissose granites are stated to represent 'predominantly reactivated Archaean basement'. However, zircon $\mathrm{U}-\mathrm{Pb}$ and whole-rock $\mathrm{Rb}-\mathrm{Sr}$ isochron ages obtained by van Breemen et al. (1974) did not support this contention. The age of the supposed basement was $c .1850 \mathrm{Ma}$ 
and the isotopic results did not give any indication of the presence in the investigated rocks of components derived from much older crustal material. Van Breemen et al. (1974) concluded therefore that most of the Ketilidian mobile belt consists of new Proterozoic crust.

Kalsbeek \& Taylor (1985a) have carried out Pb-isotopic measurements to test this view. Lead isotopes are particularly useful in this respect because contamination of igneous rocks with lead derived from deep, older, continental crust is often clearly reflected in the $\mathrm{Pb}-\mathrm{Pb}$ isochron diagram. Deep crustal rocks are often markedly depleted in $\mathrm{U}$ relative to $\mathrm{Pb}$, and as a consequence the increase in ${ }^{207} \mathrm{~Pb} /{ }^{204} \mathrm{~Pb}$ and ${ }^{206} \mathrm{~Pb} /{ }^{204} \mathrm{~Pb}$ by the decay of uranium is here much slower than in the mantle or in the upper crust. Rocks contaminated with such 'retarded' lead derived from deep older crust will have low initial $\mathrm{Pb}$-isotopic ratios compared to pristine mantle-derived magma of the same age, and this is particularly reflected in a displacement of the $\mathrm{Pb}-\mathrm{Pb}$ isochrons towards lower ${ }^{207} \mathrm{~Pb} /{ }^{04} \mathrm{~Pb}$ ratios in the isochron diagram. This conception is formally expressed with the help of the 'model $\mu_{1}$ ' value, which can be read off on the 'geochron' line (fig. 2). For non-contaminated, mantle-derived rocks, the model $\mu_{\mathrm{r}}$ value is a measure of the $\mathrm{U} / \mathrm{Pb}$ ratio of the mantle source. For contaminated mantle-derived magmas, or granitic rocks formed from crustally derived magmas, this is not the case. The observed model $\mu_{1}$ values for such rocks, read off on the geochron line, are the result of mixing of lead derived from the mantle with older crustal lead, and give no direct information on the $\mathrm{U} / \mathrm{Pb}$ ratio of the mantle (or crustal) source of the rocks. For non-contaminated Archaean rocks, mantle-type $\mu_{1}$ values in the order of 7.5-8.0 are most commonly found, for Proterozoic rocks they increase to c. 8 (Moorbath \& Taylor, 1981; Oversby, 1974). Values significantly lower than this are strong evidence for crustal contamination of the rocks in question (e.g. Taylor et al., 1980).

A comparison of the isochrons obtained for granites in the central part of the Ketilidian mobile belt (13 in fig. 1) with Ketilidian granites in the border zone of the Archaean craton (12, fig. 1) examplifies this: The three granites from the border zone have much lower model $\mu_{1}$ values (7.2-7.6, fig. $2 \mathrm{~A}$, Table 1$)$ than those from the central part of the mobile belt $\left(\mu_{1} c\right.$. 8.0 , which is normal for uncontaminated Proterozoic rocks). The former apparently contain large proportions of lead derived from the surrounding Archaean rocks whereas this is not the case for the Ketilidian granites farther south. This supports the contention of van Breemen et al. (1974) that probably no Archaean basement is present underneath most of the Ketilidian mobile belt. Recent Sm-Nd data of Patchett \& Bridgwater (1984) further confirm this view. These authors conclude that the Ketilidian granites they studied may contain up to c. 10-15 per cent of material derived from the Archaean craton, but that this material was incorporated into the granites via the sedimentary/volcanic rocks from which the granites were formed by partial melting.

During the investigation mentioned above, $\mathrm{Pb}-\mathrm{Pb}$ isochrons were also obtained for the gneisses of the southern part of the Archaean craton (11, fig. 1) and ages between c. 3100 Ma and $2800 \mathrm{Ma}$ were found. These isochrons, however, also define lower model $\mu_{1}$ values (7.20-7.25) than would be expected for more or less pristine late Archaean rocks (fig. 2B). The same phenomenon has been described from the Godthåbsfjord region (10, fig. 1). In this area early Archaean (c. $3600 \mathrm{Ma}$ ) and late Archaean (c. 3000-2600 Ma) gneisses occur side by side, and the late Archaean rocks often have low model $\mu_{1}$ values because of contamination at depth with lead from early Archaean rocks (Taylor et al., 1980). Gneisses from areas where no early Archaean rocks have been found (Sukkertoppen, Nordlandet and Fiskenæsset, $\mathrm{S}, \mathrm{N}$ and $\mathrm{F}$ in fig. 1) have model $\mu_{1}$ values of $c .7 .5$ (fig. $2 \mathrm{~B}$ ), which is normal for 

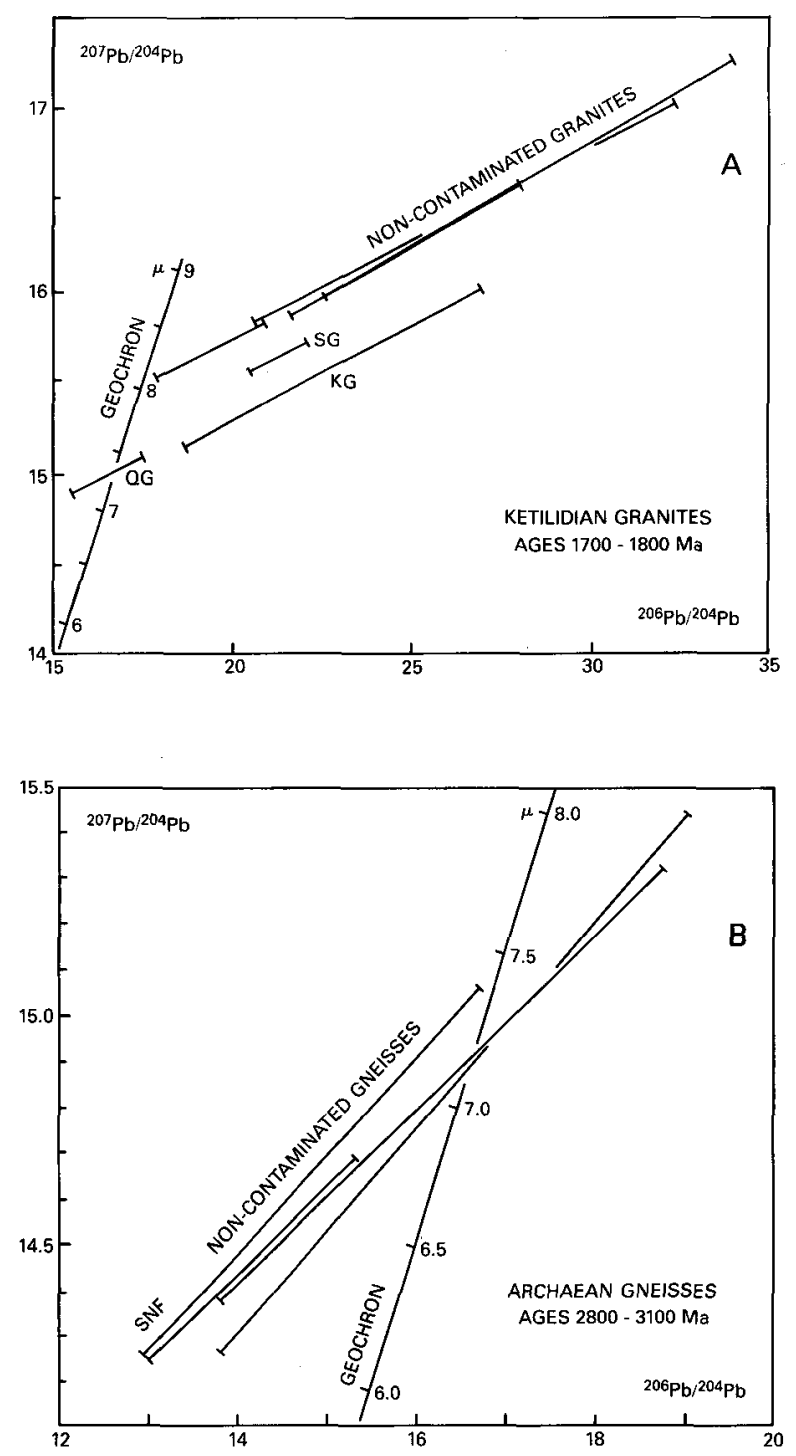

Fig. 2. Synopsis of $\mathrm{Pb}-\mathrm{Pb}$ isochrons (individual samples not shown) obtained for Ketilidian granites (A) and Archaean gneisses (B) in South Greenland. Igneous rocks contaminated at depth with lead from older rocks are characterised by a displacement of their isochrons to lower ${ }^{207} \mathrm{~Pb} /{ }^{204} \mathrm{~Pb}$ ratios compared to noncontaminated rocks. Such isochrons intersect the 'geochron' at lower model $\mu_{1}$ values than comparable noncontaminated rocks.

A. Ketilidian granites: SG, QG and KG are the Stor $\varnothing$, Quiartorfik and Kærne granites from the border zone of the Archaean craton (12, fig. 1). The other isochrons represent granites from the central part of the Ketilidian mobile belt (13, fig. 1) which are not contaminated with lead from an Archaean basement. Figure based on data of Kalsbeek \& Taylor (1985a).

B. Archaean gneisses: SNF is the isochron obtained by Taylor et al. (1980) for gneisses from Sukkertoppen, Nordlandet and Fiskenæsset (S, $\mathrm{N}$ and $\mathrm{F}$ in fig. 1) which are considered not to have been contaminated with older lead. The other three isochrons represent gneisses from the southern part of the Archaean craton (11, fig. 1). The low model $\mu_{1}$ values defined by these isochrons suggest the presence of older Archaean rocks at depth - see the text. Figure based on information from Taylor \& Kalsbeek (1985).

non-contaminated igneous rocks of that age. Early Archaean rocks have not been found in the southern part of the craton, but the low model $\mu_{1}$ values found for the late Archaean gneisses suggest their presence at depth (Taylor \& Kalsbeek, 1985). This suggestion is supported by $\mathrm{Pb}$-isotope data obtained for a c. $2150 \mathrm{Ma}$ 'MD' (dolerite) dyke in the southern part of the Archaean craton. The Pb-isotopic composition of this dyke indicates such a low model $\mu_{1}$, that derivation of a large proportion of the lead from early Archaean rocks at depth is an almost inevitable conclusion (Kalsbeek \& Taylor, 1985b).

At first sight it may appear strange that the isotopic composition of the lead in Proterozoic 
intrusions may be used to deduce the age of the Archaean rocks in the deep crust underlying these intrusions. Nevertheless, one of the first pieces of evidence for the presence of Archaean rocks in Greenland was derived from Pb-isotopic analyses of galena - not from the Archaean rocks themselves, but from the $c .1250$ Ma cryolite body at Ivigtut (Slawson et al., 1963).

\section{Relations between Archaean and Proterozoic tectonic units in the Greenland shield}

Archaean rocks have now been recognised over most of Greenland (fig. 1) and this leads to the question whether these, together with similar Archaean rocks in Canada, Scotland and Norway, once formed a continuous continental unit, or whether they represent a number of originally dispersed 'micro continents' (cf. detailed discussions on Archaean and Proterozoic crustal evolution in Windley, 1977 and Kröner, 1981).

Orogenic activity was widespread over most of Greenland during the Proterozoic, and such activity is most commonly related to plate margins rather than within-plate settings. Still, apart from the northern border of the Ketilidian mobile belt where the Archaean craton ends, no independent evidence of the presence of plate margins has yet been described. However, the $\mathrm{Pb}-\mathrm{Pb}$ isochrons obtained for the Proterozoic gneisses from Nordre Strømfjord in the Nagssugtoqidian mobile belt (9 in fig. 1) give no evidence that these rocks contain lead derived from Archaean rocks (Kalsbeek et al., 1984; see also Table 1). The isochrons define model $\mu_{1}$ values of $c .8 .0$ which is normal for non-contaminated Proterozoic rocks. This suggests that no Archaean rocks were present near the place where these rocks were formed and it is possible that the Nordre Strømfjord area contains a suture between two originally separated Archaean miniplates. A geochemical study of the supracrustal rocks in the Nordre Strømfjord area (Rehkopff, 1984) shows that parts of these rocks are of volcanic origin and have a distinct calc-alkaline chemical signature. At present such rocks are found at 'destructive' plate boundaries, and if this was also the case during the Proterozoic it would support the presence of an ancient plate margin in this area. Much more field and isotope work will be required to substantiate this suggestion and to see whether comparable evidence for other possible plate margins can be found elsewhere within the Greenland shield.

Acknowledgements. The writer is indebted to Dr K. Ellitsgaard-Rasmussen, former director of the GGU, for encouragement during his first steps in the field of isotope geology. Long-standing cooperation with Stephen Moorbath and Paul Taylor (Oxford University), Ole Larsen (University of Copenhagen) and Bob Pidgeon (Western Australian Institute of Technology) is gratefully acknowledged. The geochronological facilities at Oxford, where a large part of the data were collected, are funded by a grant from the Natural Environment Research Council to Dr S. Moorbath. The laboratories for isotope geology and X-ray fluorescence spectrometry of the Institute of Petrology, University of Copenhagen, where most of the Rb-Sr isotope work was done, are supported by the Danish Natural Science Research Council (SNF). 


\section{References}

Andersen, M. C. 1981: En geologisk undersøgelse af den SV-lige del af Drygalskis Halvø, Umanak Fjord, Vestgrønland, med specielt henblik på radiometrisk aldersbestemmelse. Unpublished thesis, University of Copenhagen.

Black, L. P., Gale, N. H., Moorbath, S., Pankhurst, R. J. \& McGregor, V. R. 1971: Isotopic dating of very early Precambrian amphibolite facies gneisses from the Godthåb district, West Greenland. Earth planet. Sci. Lett. 12, 245-259.

Bondesen, E. 1970: The stratigraphy and deformation of the Precambrian rocks of the Grænseland area, South-West Greenland. Bull. Grønlands geol. Unders. 86 (also Meddr Grønland 185, 1) 210 pp.

Bridgwater, D., Keto, L., McGregor, V. R. \& Myers, J. S. 1976: Archaean gneiss complex of Greenland. In Escher, A. \& Watt, W. S. (edit.) Geology of Greenland, 19-75. Copenhagen: Geol. Surv. Greenland.

Escher, A. \& Pulvertaft, T. C. R. 1976: Rinkian mobile belt of West Greenland. In Escher, A. \& Watt, W. S. (edit.) Geology of Greenland, 104-119. Copenhagen: Geol. Surv. Greenland.

Escher, A. \& Watt, W. S. 1976: Summary of the geology of Greenland. In Escher, A. \& Watt, W. S. (edit.) Geology of Greenland, 10-16. Copenhagen: Geol. Surv. Greenland.

Escher, A., Sørensen, K. \& Zeck, H. P. 1976: Nagssugtoqidian mobile belt in West Greenland. In Escher, A. \& Watt, W. S. (edit.) Geology of Greenland, 76-95. Copenhagen: Geol. Surv. Greenland.

Garde, A. A. \& Pulvertaft, T. C. R. 1976: Age relations of the Marmorilik Marble Formation, central West Greenland. Rapp. Grønlands geol. Unders. 80, 49-53.

Gulson, B. L. \& Krogh, T. E. 1975: Evidence of multiple intrusion, possible resetting of U-Pb ages, and new crystallisation of zircons in the post-tectonic intrusions ('Rapakivi granites') and gneisses from South Greenland. Geochim. cosmochim. Acta 39, 65-82.

Hickman, M. H. 1979: A Rb-Sr age and isotope study of the Ikertôq, Nordre Strømfjord, and Evighedsfjord shear belts, West Greenland - outline and preliminary results. Rapp. Grønlands geol. Unders. 89, 125-128.

Hickman, M. H. \& Glassley, W. E. 1984: The role of metamorphic fluid transport in the Rb-Sr isotopic resetting of shear zones: evidence from Nordre Strømfjord, West Greenland. Contr. Miner. Petrol. 87, 265-281.

Kalsbeek, F. 1979: Rb-Sr isotope evidence on the age of the Nagssugtoqidian orogeny in West Greenland, with remarks on the use of the term 'Nagssugtoqidian'. Rapp. Grønlands geol. Unders. 89, 129131.

Kalsbeek, F. 1981: The northward extent of the Archaean basement of Greenland - a review of Rb-Sr whole-rock ages. Precambrian Res. 14, 203-219.

Kalsbeek, F. \& Dawes, P. R. 1980: Rb-Sr whole-rock measurements of the Kap York meta-igneous complex, Thule district, North-West Greenland. Rapp. Grønlands geol. Unders. 100, 30-33.

Kalsbeek, F. \& Taylor, P. N. 1985a: Isotopic and chemical variation in granites across a Proterozoic continental margin - the Ketilidian mobile belt of South Greenland. Earth planet. Sci. Lett. 73, 65-80.

Kalsbeek, F. \& Taylor, P. N. 1985b: Age and origin of early Proterozoic dolerite dykes in South-West Greenland. Contr. Miner. Petrol. 89, 307-316.

Kalsbeek, F. \& Zeck, H. P. 1978: Preliminary Rb-Sr whole-rock data for Archaean and Nagssugtoqidian rocks from the Søndre Strømfjord area, West Greenland. Rapp. Grønlands geol. Unders. 90, 129-134.

Kalsbeek, F. \& Zeck, H. P. in press: Dykes and deformation in the Ikertôq zone of the Nagssugtoqidian at Søndre Strømfjord Airport, West Greenland - a discussion. Bull. geol. Soc. Denmark 34, 213-217.

Kalsbeek, F., Bridgwater, D. \& Zeck, H. P. 1978: A $1950 \pm 60 \mathrm{Ma} \mathrm{Rb-Sr}$ whole-rock isochron age from two Kangâmiut dykes and the timing of the Nagssugtoqidian (Hudsonian) orogeny in West Greenland. Can. J. Earth Sci. 15, 1122-1128. 
Kalsbeek, F., Taylor. P. N. \& Henriksen, N. 1984: Age of rocks, structures and metamorphism in the Nagssugtoqidian mobile belt, West Greenland: field and Pb-isotope evidence. Can. J. Earth Sci. 21, 1126-1131.

Kröner, A. (edit.) 1981: Precambrian plate tectonics. Amsterdam: Elsevier, 781 pp.

Larsen, O. \& Møller, J. 1968: Potassium-argon age studies in West Greenland. Can. J. Earth Sci. 5, 683-691.

McGregor, V. R. 1973: The early Precambrian gneisses of the Godthåb district, West Greenland. Phil. Trans. R. Soc. Lond. A. 273, 343-358.

Moorbath, S. \& Taylor, P. N. 1981: Isotopic evidence for continental growth in the Precambrian. In Kröner, A. (edit.) Precambrian plate tectonics, 491-525. Amsterdam: Elsevier.

Oversby, V. M. 1974: New look at the lead isotope growth curve. Nature 248, 132-133.

Patchett, P. J. \& Bridgwater, D. 1984: Origin of continental crust of 1.9-1.7 Ga defined by Nd isotopes in the Ketilidian terrain of South Greenland. Contr. Miner. Petrol. 87, 311-318.

Ramberg, H. 1948: On the petrogenesis of the gneiss complexes between Sukkertoppen and Christianshaab, West Greenland. Meddr dansk geol. Foren. 11, 312-327.

Rehkopff, A. 1984: Origin of quartzo-feldspathic supracrustal rocks from the central part of the Nagssugtogidian mobile belt of West Greenland. Rapp. Grønlands geol. Unders. 117, $26 \mathrm{pp}$.

Steiger, R. H. \& Jäger, E. 1977: Subcommission on Geochronology: Convention on the use of decay constants in geo- and cosmochronology. Earth planet. Sci. Lett. 36, 359-362.

Slawson, W. F., Kanasewich, E. R., Ostic, R. G. \& Farquhar, R. M. 1963: Age of the North American crust. Nature 200, 413-414.

Taylor, P. N., Moorbath, S., Goodwin, R. \& Petrykowski, A. C. 1980: Crustal contamination as an indicator of the extent of early Archaean continental crust: Pb isotopic evidence from the late Archaean gneisses of West Greenland. Geochim. cosmochim. Acta 44, 1437-1453.

Taylor, P. N. \& Kalsbeek, F. 1985: Pb isotopic evidence for Early Archaean crust in South Greenland. In Abstracts presented to the workshop 'Early crustal genesis; the world's oldest rocks', 23-26. Houston: Lunar and Planetary Institute.

Van Breemen, O., Aftalion, M. \& Allaart, J. H. 1974: Isotopic and geochronologic studies in granites from the Ketilidian mobile belt of South Greenland. Bull. geol. Soc. Am. 85, 403-412.

Wegmann, C. E. 1938: Geological investigations in southern Greenland. I. On the structural divisions of southern Greenland. Meddr Grønland 113(2), $148 \mathrm{pp}$.

Windley, B. F. 1977: The evolving continents. London, New York, Sidney, Toronto: John Wiley \& Sons, $385 \mathrm{pp}$.

Geological Survey of Greenland,

$\emptyset$ ster Voldgade 10,

DK-1350 Copenhagen $K$,

Denmark. 